\title{
Muddying the Waters: managing agricultural water quality in New Zealand
}

\author{
Russell Harding
}

\author{
Nā wai i tara ai te wai? \\ Who disturbed the water?
}

\section{Introduction}

Despite heightened public opinion over a number of years, considerable expenditure of money and concerted effort, freshwater pollution continues to be a public problem in New Zealand. For many years New Zealanders seem to have believed that they were immune from this, confident in their 'clean green' image, and that rain and snow melt flush unwanted substances and organisms out of lakes and rivers. New Zealand's 'clean green' image continues to work well as a marketing slogan for New Zealand products internationally, but is often belied by conditions in the environment.

Over the past four years there has been a flurry of initiatives to address water quality in agricultural areas. The first down the race was the Dairying and Clean Streams Accord between Fonterra Co-operative Group, regional councils, the minister for the environment and the minister of agriculture. Commenced in 1999, the accord was signed on 26 May 2003. Next came central government's Sustainable Development for New Zealand: programme of action. This document, released in January 2003, identified four issues requiring action, one of which was water quality. This has been assigned to second place because, while it was released in January 2003, much of the detail of what was to become the Water Programme of Action was not worked out until 2004 and 2005. Indeed, parts of it continue to evolve today. Finally, in March 2006 Dairy Insight's Dairy Industry Strategy for Sustainable Environmental Management was released.

This article examines the approach each of these takes to addressing water quality in agricultural areas. It also examines the relationship between them. While each initiative has been developed in full knowledge of its chronological antecedents, each is, in many respects, an independent initiative. None alone provides a comprehensive approach to managing water quality, yet all three together fall short of an integrated approach. On one hand, the accord focuses on specific actions on the ground, with performance targets, whereas the other two take a broader, strategic planning approach. None establishes water quality standards designed to support water uses. One prescribes actions in the absence of a water quality attainment standard; the other two describe a framework, leaving both actions and standards to emerge as a result of a government and stakeholder planning process. Taken together, the ground-up action approach and the planning process top-down approach fall short of meeting in the middle. The development of these three initiatives seems to have been driven more by a desire to control a public issue than to achieve clean water. Despite this, it is notable that three influential organisations are involved in this issue. Their involvement is necessary for water quality to improve, but it may not be sufficient.

\section{Green but not so clean}

On 26 May 2003 the Dairying and Clean Streams Accord was signed by the chair of Fonterra Co-operative Group, the chair of the regional affairs committee of Local Government New Zealand, representing 12 regional councils, the minister for the environment and the minister of agriculture. The accord was an industryled and initiated voluntary approach to water quality in dairy farming areas.

Its genesis, however, was not nearly as altruistic. In 1999 Tourism New Zealand released its global marketing campaign designed to entice tourists to 'one hundred per cent pure New Zealand'. In 2001, news programmes on television showed images of cows trampling stream 
banks and defecating in streams, in stark contrast to the tourist campaign. Farmers (through Federated Farmers) and environmentalists (largely through the efforts of the New Zealand Fish and Game Council) took opposing positions in response to the images. Through a media campaign the New Zealand Fish and Game Council challenged farmers to address 'dirty dairying', a catchphrase for a campaign to clean up fouled waterways (ANZSOG, 2004, p.3).

If the relationship between the New Zealand Fish and Game Council and Federated Farmers was contentious, nor were things entirely harmonious within government. The Waikato Regional Council, known as Environment Waikato, with Lake Taupo and the Waikato River and $22 \%$ of the national dairy herd within its boundary, characterised the relationship with the Ministry for the Environment (MfE) as follows:

Farmers distrust them (MfE). The regional councils don't think MfE needs to be there, MfE doesn't think the regional councils are doing what they are supposed to do. MfE has the ability to bring in national standards which override the regional councils' processes for making rules. So if MfE brings in national standards, the regional councils have got to monitor and make farmers or their constituents meet them. Regional councils don't like that. They would prefer to do it their own way through their own processes. (ANZSOG, 2004, p.5)

A hint of what is meant by following their own processes and doing things their own way was given with the comment:

The power of voluntary commitment, particularly when you are dealing with the agriculture sector, is huge. If you get people to be part of the solution, you get momentum, enthusiasm, resources poured into something they voluntarily support. If you tell a farmer what to do, [you will get resistance]. [Brackets in original] (ANZSOG, 2004, p.4)

The eventual accord grew from initial discussions between the chief executives of Environment Waikato and Fonterra Co-operative Group. Drafting of the accord was, however, not a democratic process. Those involved in drafting the accord were representatives from the Ministry for the Environment, the Ministry of Agriculture and Forestry, Fonterra Co-operative Group and Environment Waikato. Federated Farmers and the New Zealand Fish and Game Council were actively excluded from the discussions. Not surprisingly, much criticism surrounded the perceived secrecy of the discussions. Federated Farmers characterised the agreement as Fonterra using its monopoly to impose conditions on its suppliers. The ACT political party claimed that the New Zealand Fish and Game Council had always been involved and that the agreement represented its position (ANZSOG, 2004a, p.2).

The accord itself is a brief, five-page document. It admits immediately that dairy farming has an impact on water quality, and envisages an industry-led regime to address these impacts. It is a voluntary, non-legally binding agreement. The goal of the accord is that:

Fonterra Co-operative Group, regional councils and unitary authorities, the Ministry for the Environment, and the Ministry of Agriculture and Forestry will work together to achieve clean healthy water, including streams, rivers, lakes, ground water and wetlands, in dairying areas. (Fonterra Co-operative Group et al., 2003, p.1)

The specific goal to be achieved is water that is suitable, where appropriate, for fish, stock drinking and swimming in areas designated by regional councils. The words 'where appropriate' are important. They imply places where water suitable for fish, swimming and stock watering may not be appropriate, and where this standard will not be provided. Clean and green may apply only to some areas, not all.

The accord lists a number of principles. These fall into two categories: principles governing the types of action that may be undertaken, and principles surrounding the interactions between the parties. Further discussion on the former appears below. On the relationship side, there is the almost obligatory principle of co-operation and mutual assistance to achieve the purposes of the accord, including encouragement of 'a strategic, cohesive partnership approach'. The last principle listed may be the most important for Fonterra, namely, acknowledgement of 'the lead role of the dairy industry in the Accord' (Fonterra Co-operative Group et al., 2003, p.2).

The final principle signals a clear shift in leadership from central government to the industry, and particularly to Fonterra Co-operative Group. If it had stopped at this 
point, the accord would have been little more than an attempt by the dairy industry to wrest control of water quality in dairy farming areas from central government. This feature of the accord, particularly, must have alarmed the New Zealand Fish and Game Council, as it saw water quality in dairy farming areas being transferred from central government with its coercive, regulation-making power to a voluntary, industry-led initiative. It is this that led the chair of the New Zealand Fish and Game Council to comment:

New Zealand's 'clean and green' image will remain a sham if the wimpy document we were shown turns out to be the real thing signed in Parliament tomorrow night. (ANZSOG, 2004, p.15)

The accord continues, however, with a series of priority actions and performance targets. These are:

- Dairy cattle are excluded from $50 \%$ of streams, rivers and lakes and their banks by 2007 , and $90 \%$ by 2012 .

- Where stock cross a watercourse more than twice a week, $50 \%$ of crossing points have bridges or culverts by 2007 , and $90 \%$ by 2012 .

- Farm dairy effluent is appropriately treated and discharged. All farm dairy effluent discharges to comply with resource consents and regional plans immediately.

- Nutrients are managed effectively to minimise losses to ground and surface waters. All dairy farms to have in place systems to manage nutrient inputs and outputs by 2007 .

- Existing regionally significant or important wetlands (as defined by regional councils) are fenced and their natural water regimes are protected. The performance target is $50 \%$ of regionally significant wetlands to be fenced by 2005 , and $90 \%$ by 2007 .

- Fonterra and regional councils develop regional action plans for the main dairying regions to implement the accord by June 2004. (Fonterra Cooperative Group et al., 2003, pp.2-3)

The first action above has three modifiers that accompany it. These are:

a) Fencing may not be required where natural barriers prevent stock access. b) The type of fencing will depend on factors such as terrain, stock type and costs.

c) Streams are defined as deeper than a 'Red Band' (ankle depth) and 'wider than a stride', and permanently flowing.

These are consistent with principles spelled out in the accord, namely that measures must be 'cost effective', 'practical to implement in the context of existing farming operations', and 'clearly recognise the practical and financial constraints to implementation timeframes' (Fonterra Co-operative Group et al., 2003, p.2).

No matter the water quality outcomes from the accord, these principles address an important principle from the dairy industry's viewpoint, namely, the principle of commensuration. Two items are commensurable if they are able to be specified in the same units. For example, being able to compare a hydroelectric dam with the needs of migrating fish and recreational uses requires that each of these three be able to be specified in common terms. The most common unit used is monetary; hence the cost-benefit equation. If the dam, fish and recreation can be specified in terms of dollars produced (from electricity generated, fishing outfitters and charter operators, and kayaking and aesthetics), then a calculation can be made of the most 'efficient' use of a waterway. For some environmental advocates, by contrast, the environment is incommensurable, i.e. it cannot be translated into other units to enable it to be compared with something else. They argue that the values inherent in the environment are so unique and of such high standing that they cannot, and ought not to, be traded off against other values. For Fonterra Co-operative Group it was important to establish the principle that water quality and practical farming had to be able to be directly compared in order to determine an appropriate course of action.

The New Zealand Fish and Game Council's characterisation of the accord as 'wimpy' underlines the council's view that the accord does not come close to addressing the incommensurable set of values enshrined in clean water. The council's chair was particularly critical of the ultimate $90 \%$ targets, focusing instead on the $10 \%$ 'worst pollution offenders' (ANZSOG, 2004, p.15). The council may have been worried that commensuration would always lead to the environment being the value that is traded away in favour of 
affordability or practicability, or on the grounds of inappropriateness of a location for suitable water quality for fish, swimming or stock watering.

The accord concluded by describing the roles of the participants. The focus of regional councils will be working with Fonterra Co-operative Group to develop regional action plans for dairying regions. The purpose of these plans, which are not legally binding, is to identify local commitments of Fonterra Co-operative Group and regional councils. In part they modify the accord by providing for amended regional time-bound targets for the priority actions. They are also designed to identify regionally important resources, such as wetlands and water bodies suitable for swimming, detailing how the councils and Fonterra Co-operative Group will work together, a statement on the compliance and monitoring roles of Fonterra Co-operative Group and the councils, and a protocol for reporting on and reviewing the action plans. The plans could also be used to amend regional plans under the Resource Management Act and to capture commitments from other parties, such as Federated Farmers or the New Zealand Fish and Game Council.

Fonterra Co-operative Group's role is largely that of providing information, promoting best practices, developing an assessment scheme to ensure targets are met, continuing to develop a market-based approach to farm environmental management, and reporting publicly on progress. Perhaps the item with the greatest leverage is Fonterra Co-operative Group's ability to establish arrangements with its supplying farmers to ensure the accord's priority targets are met. In this regard it has usurped government's regulatory role.

The ministries for the Environment and of Agriculture and Forestry are relegated to publicly supporting the accord, monitoring overall progress, developing tools to support achievement of the targets, identifying institutional and legislative barriers, and working with councils and Fonterra Co-operative Group on science and research needs for the accord.

The accord captured three main beliefs for the dairy industry:

- industry leadership;

- voluntary actions; and

- considering water quality as one of a number of competing issues.
Three progress reports on the results of the accord have now been produced, covering 2003/04, 2004/05 and 2005/06. These results are contained in Table 1. Table 1: Progress towards accord targets
2003-2006

\begin{tabular}{|l|l|l|l|}
\hline Accord Target & 2003/04 & 2004/05 & 2005/06 \\
\hline $\begin{array}{l}\text { Dairy cattle excluded } \\
\text { from streams, rivers } \\
\text { and lakes }\end{array}$ & $67 \%$ & $72 \%$ & $75 \%$ \\
\hline $\begin{array}{l}\text { Regular race } \\
\text { crossings have } \\
\text { bridges or culverts }\end{array}$ & $92 \%$ & $93 \%$ & $93 \%$ \\
\hline $\begin{array}{l}\text { Dairy effluent is } \\
\text { appropriately treated } \\
\text { and discharged }\end{array}$ & $\mathrm{n} / \mathrm{a}$ & $\begin{array}{l}\text { Average } \\
\text { compliance level } \\
\text { of } 67 \% \text { nationally }\end{array}$ \\
\hline $\begin{array}{l}\text { Nutrients are } \\
\text { managed }\end{array}$ & $17 \%$ & 19\% & $33 \%$ \\
\hline
\end{tabular}

Source: 'The Dairying and Clean Streams Accord: snapshot of progress - 2005/2006', p.2, accessed from http://www.mfe.govt.nz/ publications/land/dairying-clean-streams-accord-snapshot-mar07/ dairying-clean-steams-accord-snapshot-mar07.pdf, 16 July 2007.

While percentages of cows excluded from waterways has shown continued improvement, the numbers of cows entering waterbodies could nonetheless increase based on herd size. It should be noted that nationally the number of dairy cows has remained relatively stable over the past five years at around 5.1 million animals.

\section{Sustainable water programme of action}

At the time the above accord was being negotiated, the ministry for the environment had commenced work on a national standard and regulatory regime that could be imposed on farmers country-wide. This was subsequently folded into the government's Sustainable Development for New Zealand: programme of action, released in January 2003. Marian Hobbs, then minister for the environment and minister with responsibility for urban affairs, stated that ' $[\mathrm{t}]$ he government has a key leadership role of articulating outcomes and directions for New Zealand' (Department of Prime Minister and Cabinet, 2003, p.5). This is an important, if tautologous, assertion in light of the dairy industry's assertion of leadership in water quality. This programme had four separate elements, one of which was freshwater quality and allocation. The government established 
an overarching goal of '[a]dequate, clean freshwater available for all', and an outcome related to water quality of 'freshwater quality maintained to meet all appropriate uses' (Department of Prime Minister and Cabinet, 2003, p.13).

The use of the words 'adequate' and 'appropriate' here obscures the relationship between water quality and other factors that may be weighed against it. Where Fonterra Co-operative Group wished water quality to be completely commensurable with financial and farming operations, the government seems to be hedging its bets.

In commenting specifically on the second outcome, the document noted that:

New Zealand has made significant progress in reducing direct discharges of human and agricultural sewage and industrial waste into our waterways, although the quality of some water bodies remains poor. In particular, the quality of many lowland streams, lakes, ground waters and wetlands in areas of intensive land use continue to fall below acceptable standards. Water abstraction, urban and industrial uses, intensive farming activities, rapid urban growth, discharges, and diffuse runoff into waterways and groundwater, all contribute to reduced water quality. The main issue is diffuse discharges, such as urban and agricultural runoff. But reducing these types of discharges is often difficult and complex. (Department of Prime Minister and Cabinet, 2003, p.14)

The Water Programme of Action is to be managed under the Resource Management Act 1991. The stated aim of the act is to promote the sustainable management of land, sea, air and water in New Zealand. The role of central government under the Resource Management Act is promulgating national policy statements, establishing national environmental (water quality) standards, commenting on councils' plans, and having the governor-general issue water conservation orders to protect waters with high intrinsic values. Water conservation orders allow waters to be used, but protects environmental values as paramount.

Day-to-day administration of the act resides with local and regional councils. The means by which the act is administered is largely through a planning process. Regional policy statements are compiled, followed by regional and district plans. These are developed through a public process, and permits (resource consents) are issued for allowed activities. Local government is responsible for making decisions on the allocation and use of water within its area. Councils determine social, economic, environmental and cultural outcomes relating to water quality for their communities. Operationally, regional councils develop regional policy statements and regional plans. Councils may use these plans to set water quality standards and to manage land use activities that affect water quality. Councils are expressly required to authorise discharges into water, and do this through either rules in the plan or conditions in resource consents.

In November 2004, Cabinet approved the release of a discussion document entitled Freshwater for a Sustainable Future: issues and options. The paper characterised the current state of freshwater management, described a future management regime, and sought public comments. A series of 'Action Items' was listed. The items relating to water quality included:

- Develop national policy statements.

- Develop national environmental standards.

- Address nationally important values.

- Develop market mechanisms to manage diffuse discharges. This includes transferable discharge permits.

Following receipt of public submissions on the discussion document, six broad goals were reported as having arisen from the public consultation. These were:

- achieve greater strategic planning for water at national and regional levels;

- provide clearer direction and guidance from central government;

- ensure greater consistency in the way increasing demands on water are managed across the country;

- develop a better framework for deciding between conflicting demands for water;

- enable increased effectiveness of Māori participation in water management; and

- provide for more effective management of the impacts of diffuse or unintended discharges on water quality. 
Three national outcomes for freshwater were specified. These were:

- improve the quality and efficient use of freshwater by building and enhancing partnerships with local government, industry, Māori, science agencies and providers, and rural and urban communities;

- improve the management of the undesirable effects of land use on water quality through increased national direction and partnerships with communities and resource users; and

- provide for increasing demands on water resources and encourage efficient water management through national direction, working with local government on options for supporting and enhancing local decision making, and developing best practice.

The specific actions included establishing a 'leadership group' with diverse membership to advise the minister for the environment and minister of agriculture and forestry on priorities for water management; to provide national direction on a number of issues related to water demand and measurement; to identify water catchments that are 'sensitive' and 'at risk' from urban and rural diffuse discharges and establish criteria to determine nationally outstanding water bodies; and to provide 'tools' to assist regional councils to perform their role in water management. In terms of water quality, the two ministries were to report back by 28 March 2007 'on the potential and options for a national Policy Statement on nutrients and microbial contaminants, and sediment'. In that report back, the following recommendation was made:

6. Agree that the Minister of Agriculture and Forestry and the Minister for the Environment report to Cabinet by 28 March 2007 on either:

a. one draft National Policy Statement on the management of freshwater to assist in meeting the water demands and water quality objectives of the Programme or

b. a draft National Policy Statement for managing increasing demands for water; and the potential value of and options for a National Policy Statement on nutrients, microbial contaminants and sediment as directed [Cab Min (06) 11/11 refers];
7. Agree that if Recommendation 6a. is preferred, to rescind the decision in [Cab Min (06) 11/11] that the Minister of Agriculture and Forestry and the Minister for the Environment report to Cabinet by 28 March 2007 on a draft National Policy Statement for managing increasing demands for water; and the potential value of and options for a National Policy Statement on nutrients, microbial contaminants and sediment.

Ultimately, Cabinet agreed that the ministers report on a single draft national policy statement only, on the management of freshwater for both quantity (allocation) and quality. With a pun entirely intended, the water quality aspect of the Water Programme of Action seems to have watered down the initial effort towards a national water quality standard.

Unable to assert a leadership role in the face of the practical Clean Streams Accord, central government seems to be taking the approach that if the dairy sector is folded in with a number of other sectors, perhaps its influence and the impact of the accord can be watered down.

Māori involvement with water has focused largely on quantity, allocation and ownership. In this regard, central government's Water Programme of Action has been described as:

An attempt to provide a national strategy to improve management and determine how to fairly use, protect and preserve water. But it is a ponderous process and could be too little too late. (Hipkins, 2006, p.14)

\section{Sustainable environmental management}

In March 2006 Dairy Insight, a dairy farmer-owned research and education organisation, produced a report entitled Dairy Industry Strategy for Sustainable Environmental Management. This is a high-level strategic document that identifies three outcome areas:

- leadership and engagement;

- action; and

- research.

A brochure released in conjunction with this publication contained a number of questions with answers. A natural question is: what is the relationship between this document and the accord? The answer provided in the brochure is: 
Isn't the Clean Streams Accord doing this already?

Monitoring undertaken as a result of the Accord has shown that huge advances in managing riparian strips and waterway access have been made. The strategy aims to build on this work in a broader sense with a focus on target catchments. (Dairy Insight, 2006)

Dairy Insight appears to be trying to assert itself environmentally by supplanting Fonterra Co-operative Group's accord with its own strategy, and by trying to incorporate the accord into a wider 'strategic' framework. It will be interesting to watch these three initiatives as they unfold over time. It is unlikely that those who have championed the, at times, arcane issue of water quality ever envisioned that organisations would compete over the right to be the one that champions the cause.

Central government's rejoinder was published in April 2006. Entitled Freshwater for the Future: a supporting document, the paper lays out a further series of actions. Of particular note under 'Action 1.3: Build partnerships with industry sectors', is the following:

19. Central government will seek to strengthen partnerships with industry by:

- Building on initiatives such as the Dairying and Clean Streams Accord and the proposed Dairy Industry Strategy for Sustainable Environmental Management (Ministry for the Environment, 2006b, p.5)

While it appears that the ministry is being even-handed in its approach to the two industry initiatives, at 'Action 2.3: Provide targeted assistance to land users', only Dairy Insight's Dairy Industry Strategy for Sustainable Environmental Management is cited (Ministry for the Environment, 2006b, p.9). Targeted assistance usually refers to money, and there are few more decisive resources for asserting influence.

Where the ministry is hedging its bets is back where it started, on the outcome of a national policy statement on nutrients, microbial contaminants and sediment on water bodies. A national policy statement would have to be incorporated into regional plans under the Resource Management Act. While not as stringent as a national standard, a policy statement helps to reassert the incommensurability of the environment. It requires that a national policy be incorporated into regional plans, without local discussion. It loses some of its force in that the Resource Management Act itself is a vehicle for making decisions based on commensuration.

In advancing its argument, the ministry cites a report from the parliamentary environment commissioner entitled Growing for Good: intensive farming, sustainability and New Zealand's environment. In this report the parliamentary commissioner, in considering nutrient management, comments on the relative merits of voluntary versus mandatory actions:

A suite of tools, management practises and policy instruments are [sic] available (some of which have been discussed in Chapter 6). Given the declining trends in the quality of the environment, particularly fresh water, it would appear the voluntary approaches used to date are not sufficient. Regulation will probably be required. The exact type of approach would be best developed with the characteristics of individual catchments in mind. (Parliamentary Commissioner for the Environment, 2004, p.185)

None of the initiatives promulgated to date has established, or overtly seeks to establish, measurable water quality criteria. The result may be success in meeting measures specified in the programme, but this may bear little or no relation to water quality improvement.

Perhaps, in the end, this will be a contest between on-theground practices versus planning: central government's Sustainable Water Programme of Action, or Dairy Insight's Dairy Strategy for Sustainable Environmental Management. Who gets to pollute has always been political. The experience of the last four years suggests that cleaning up pollution has become equally political. The 'winner' gets not only to clean up water to his/her standard, but to define how water quality fits into the overall ambit of public policy issues.

Of course, despite all this, the fate of the quality of water in agricultural areas is unclear. It may be that the prominence of the issue is all we get. Aaron Wildavsky captured it well in his prominent work on public policy in which he reports on the work of the Delaware River Basin Commission. Of its efforts to deal with pollution he writes:

The effort was (and is) the largest aimed to clean up our rivers. The work involves five states, hundreds of 
millions of dollars, and extensive efforts at the most modern technical analyses of costs and benefits. In its economic rationale and political process it is typical of environmental policymaking. It is also a failure. Of course, the river will be cleaned up in some sense of the term except that, for the most part, the Delaware will remain unswimmable, unboatable, unsightly, and only slightly more fishable, smellable and potable. That is not much gain for approximately three quarters of a billion dollars, not much, that is, if you value results. But if the cleaning is what you value, if your aim is the ritual of purification, then the whole thing is a rip-roaring success. (Wildavsky, 1987, p.184)

There is no doubt that New Zealand's rivers, too, will be cleaned up to some extent. At this stage, though, government and dairy farmers seem to be in the early stages of the activity of cleaning. It could also be that the government and the dairy farming industry are not involved in the ritual of water purification as much as they are involved in the ritual of public policy in practice. The old formulation of 'who gets what' seems to apply here - who gets to control the water quality issue. Fonterra Co-operative Group's opening shot of action on-the-ground seems to have been initially decisive. If it wishes to keep its prominent position as the dairy industry's environmental champion, it will have to hold off strong challenges from central government and other industry organisations.

\section{References}

ANZSOG (2004) A Voluntary Environmental Accord for the Dairy Industry (A), case program 2004-7.1, version 21.3.05, Parkville, Victoria: Australia and New Zealand School of Government

ANZSOG (2004a) A Voluntary Environmental Accord for the Dairy Industry (B-epilogue), case program 2004-7.2, version 21.3.05, Parkville, Victoria: Australia and New Zealand School of Government

Dairy Insight (2006) Dairy Industry Strategy for Sustainable Environmental Management, report of the Dairy Environment Review Group, Wellington: Dairy Insight

Department of Prime Minister and Cabinet (2003) Sustainable Development for New Zealand: programme of action, Wellington: Department of Prime Minister and Cabinet
Fonterra Co-operative Group et al. (2003) Dairying and Clean Streams Accord between Fonterra Co-operative Group, regional councils, Ministry for the Environment, and Ministry of Agriculture and Forestry, Wellington: Fonterra Co-operative Group, Local Government New Zealand, Ministry for the Environment and Ministry of Agriculture and Forestry

Hipkins, G. (2006) 'Water balance urgently needed', Te Karaka, 33, summer

Ministry for the Environment (2004) Water Programme of Action: the effects of rural land use on water quality, Wellington: Ministry for the Environment

Ministry for the Environment (2004a) Freshwater for a Sustainable Future: issues and options, Wellington: Ministry for the Environment

Ministry for the Environment (2004b) The Dairying and Clean Streams Accord: snapshot of progress - 2003/2004, Wellington: Ministry for the Environment, accessed at www.mfe.govt.nz/publications/land/dairying-cleanstream-accord/, 16 July 2007

Ministry for the Environment (2004c) 'Cabinet Paper: Sustainable Water Programme of Action - implementation package', accessed at http://www. mfe.govt.nz/issues/water/prog-action/cabinet-paperimplementation-package.html, 16 July 2007

Ministry for the Environment (2006) The Dairying and Clean Streams Accord: snapshot of progress - 2004/2005, Wellington: Ministry for the Environment, accessed at http://www.mfe.govt.nz/publications/land/dairyingclean-streams-snapshot-may06/index.html, 16 July 2007

Ministry for the Environment (2006a) 'Cabinet Paper POL (06) 321: Sustainable Water Programme of Action: progress report', accessed at http://www.mfe. govt.nz/issues/water/prog-action/cab-paper-progressreport/index.html, 16 July 2007

Ministry for the Environment (2006b) Freshwater for the Future: a supporting document, Wellington: Ministry for the Environment

Ministry for the Environment (2007) The Dairying and Clean Streams Accord: snapshot of progress - 2005/2006, accessed at http://www.mfe.govt.nz/publications/land/ dairying-clean-streams-accord-snapshot-mar07/index. html, 16 July 2007 
Parliamentary Commissioner for the Environment (2004) Growing for Good: intensive farming, sustainability and New Zealand's environment, Wellington: Parliamentary Commissioner for the Environment

Wildavsky, A. (1987) Speaking Truth to Power: the art and craft of policy analysis, New Brunswick: Transaction Publishers

Russell Harding is a senior lecturer in the School of Government, VUW, where he teaches public management. His research interests include public sector ethics and natural resource management and policy. He was a natural resource advisor for the State of Oregon Department of Environmental Quality for 11 years, engaged in various aspects of water quality management. He can be contacted at Russell.Harding@vuw.ac.nz.

\section{FIGHTING A FEARFUL DISEASE: Controlling New Zealand's Meningococcal B Epidemic}

An Institute of Policy Studies publication written by Janet Tyson with Richard Norman

Fighting a Fearful Disease tells of the unique global partnership that, in record time and with a new vaccine, successfully controlled an epidemic of group B meningococcal disease in New Zealand.

It is an in-depth narrative account that covers the scientific advances, the development of policy, and collaboration in practice, as well as the human stories of triumphs and tragedies. It provides a different perspective on the policymaking and implementation process, one that lends itself to both formal and informal teaching and learning.

Published - July 2007

Format - B5 Paperback, pp 296

ISBN - 1-877347-18-3

Price - $\$ 35.00$ (including P\&P within New

Zealand)

To have a copy of Fighting a Fearful Disease and an invoice sent to you, please email, phone, fax or mail your order to:

\section{Institute of Policy Studies}

Victoria University of Wellington

Email ipos@vuw.ac.nz

Telephone +64 44635307

Fax +64 44637413

P0 Box 600, Wellington

New Zealand 